\title{
Strategies and Measures to Prevent Spread of Invasive Species
}

\author{
Gustavo Darrigran and Cristina Damborenea
}

\begin{abstract}
On the basis of the fouling caused by the golden mussel, Limnoperna fortunei, in industrial facilities and power plants (human environment), and its impacts on the ecosystem (natural environment), several strategies and measures for the mitigation of problems and prevention of further spread are discussed. At the local level, monitoring and early detection of the golden mussel can be accomplished through different methods, including those aimed at juveniles and adults, and also those aimed at their planktonic larvae. Priorities for designing bioinvasion management strategies should focus on generation of scientific knowledge, management, and actions at the sociopolitical level. Mitigation measures are closely related to the invasion phase, whereby the cost increases and the probability of eradication decreases over time.
\end{abstract}

Keywords Limnoperna fortunei · Golden mussel • Biological invasion · Prevention • Monitoring

\section{Introduction}

The golden mussel, Limnoperna fortunei (Dunker 1857), is one of the most aggressive freshwater invaders to have spread in Asia (Korea, Japan, Taiwan, Indochina) (Morton and Dinesen 2010) and in South America (Argentina, Bolivia, Brazil, Paraguay, and Uruguay) (Darrigran 2010). This invasive species has negative impacts on man-made structures (the "human environment" hereinafter), including power plants and industrial facilities. Plants are faced with problems derived from the blockage of pipelines, decreased water velocity, accumulation of shells, contamination of water by dead mussels, and clogged filters (Darrigran and Damborenea

\footnotetext{
G. Darrigran $(\bowtie) \cdot$ C. Damborenea

División Zoología Invertebrados, Museo de La Plata, Universidad Nacional de La Plata, CONICET, Paseo del Bosque s/n, 1900 La Plata, Argentina

e-mail: invasion@fcnym.unlp.edu.ar

C. Damborenea

e-mail: cdambor@fcnym.unlp.edu.ar

(C) Springer International Publishing Switzerland 2015

D. Boltovskoy (ed.), Limnoperna fortunei, Invading Nature - Springer Series

in Invasion Ecology 10, DOI 10.1007/978-3-319-13494-9 20
} 
2005; see "Impacts of Limnoperna fortunei on Man-made Structures And Control Strategies: General Overview" in this volume).

The golden mussel also has an ecological impact on the "natural environment," where it affects the water column and changes the structure of available substrata. As a result, it impacts other members of the biota and their interactions, and it consequently modifies overall ecosystem processes, thus fulfilling the role of an “ecosystem engineer" (Jones and Lawton 1994; Darrigran and Damborenea 2011; Boltovskoy and Correa 2015).

Figure 1 summarizes the mechanisms by which an alien species can be transported elsewhere with the aid of man. For L. fortunei, expansion is associated with both "transportation-related" pathways and "commerce in living organisms." In the first case, there are two primary vectors. One is ballast water. Introduction of the mussel from Southeast Asia to South America is believed to have happened via bal-

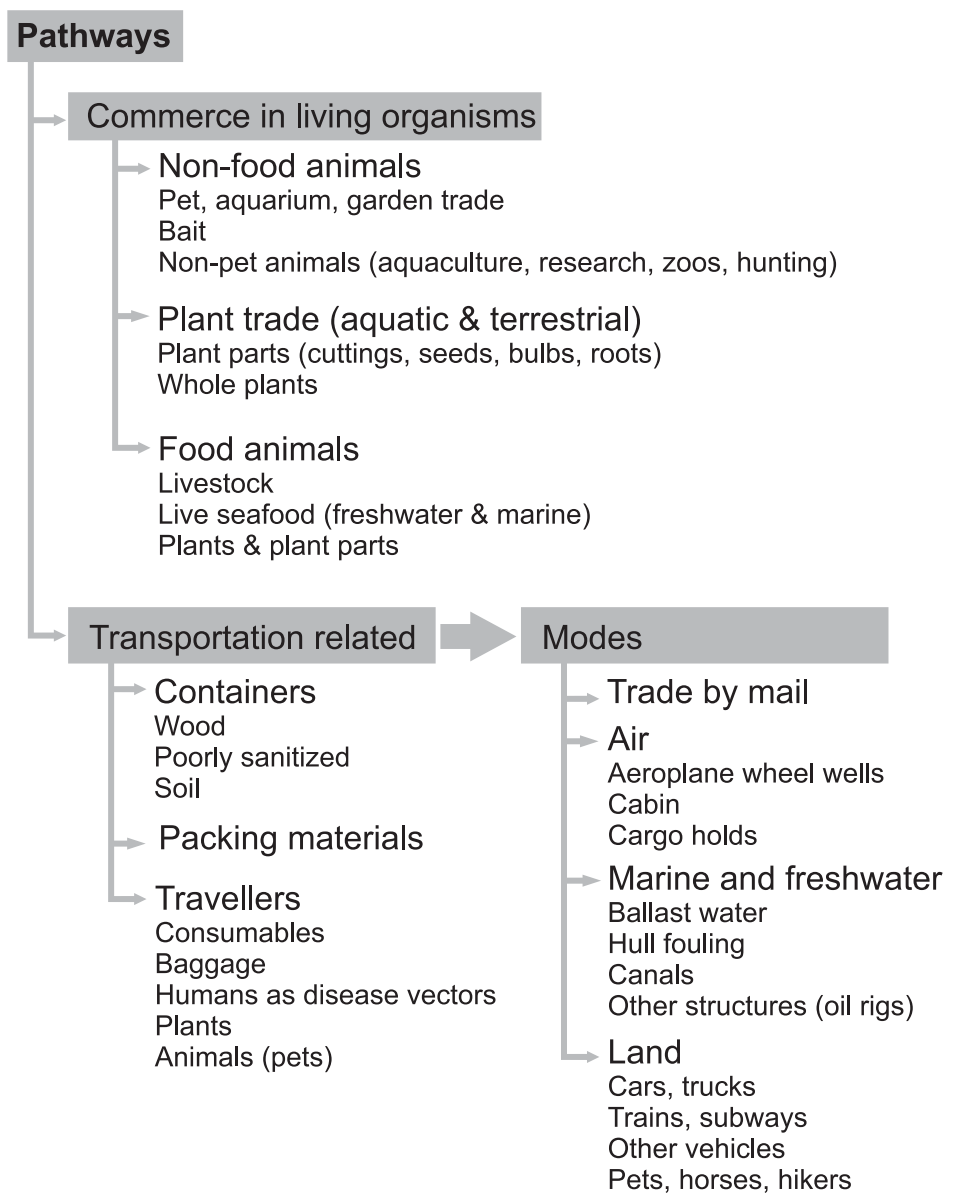

Fig. 1 Pathways responsible for the introduction of alien species 
last water (Darrigran and Pastorino 1995), and its secondary spread to the Guaíba basin in Brazil likely occurred via ballast water originating in Argentina (Darrigran and Mansur 2009). The other primary vector is hull fouling. Hull fouling is a key mechanism for intra- and interbasin expansion (see "Distribution and Colonization of Limnoperna fortunei: Special Traits of an Odd Mussel" in this volume; Boltovskoy et al. 2006; Belz et al. 2012). Commerce in living organisms (Fig. 1), in turn, is thought to have been instrumental in the introduction of the golden mussel to Japan, presumably from China and/or Korea with edible freshwater Asian clams (Corbicula fluminea) (Nishimura and Habe 1987; see "Colonization and Spread of Limnoperna fortunei in Japan" in this volume). Secondary spread is also likely when larvae are inadvertently transported between basins with live fish bait of sport fishermen, or in the guts of fishes that swallow but do not digest mussels (Belz et al. 2012).

In South America, physiographic, hydrosedimentological, and chemical conditions of the large floodplain rivers and associated water bodies of the Río de la Plata watershed are particularly favorable for the spread of L. fortunei (Darrigran et al. 2012). "Jump dispersal," which combines upstream "jumps" of adults byssally attached to ship hulls followed by downstream passive drift of planktonic larvae (MacIsaac et al. 2001), has likely been instrumental in the swift dispersal of L. fortunei throughout this watershed (Boltovskoy et al. 2006). This mechanism has allowed the golden mussel to disperse upstream at a rate of approximately $240 \mathrm{~km}$ per year along the Paraná-Paraguay rivers since its introduction (Darrigran and Damborenea 2011).

It is now clear that L. fortunei has come to stay in both Asia and South America, and we must learn to live with it. This involves developing appropriate strategies to handle this bioinvasion. An adequate management program should take into consideration that L. fortunei has invaded two types of environments: the human environment and the natural environment. In both cases, the ultimate goal should be prevention of new invasions and controlling the spread of existing ones. Actions should be implemented at various levels, from the highest global level to the local level (DePoorter 2009).

\section{Actions in the Human Environment}

Invasive species can be harmful to environmental services, with negative effects on food production, biodiversity, the health of plants, animals, and man, public infrastructures, and therefore, human welfare (Pimentel 2002). The golden mussel is no exception. It interferes with fish culturing activities (e.g., in China, Uruguay, and Brazil), and water potabilization and irrigation systems, and it affects the operation of cooling systems in power plants and industries (Darrigran 2010; see "Impacts of Limnoperna fortunei on Man-made Structures And Control Strategies: General Overview" in this volume). Thus, every installation using raw water from water bodies in areas affected by the invasion must take measures to prevent and control 
biofouling of $L$. fortunei. Planning and implementation of these measures require knowledge of the mussel's biological traits, in particular its life cycle, and the climate of the region, as well as a thorough understanding of structural and functional details of the plant in question (Mackie and Claudi 2010, Darrigran and Pereyra 2011).

Early detection of L. fortunei is critical in establishing prevention and control measures. Due to the biological characteristics of this species (planktonic larval stages and sessile benthic adults), monitoring for the presence of the golden mussel can be accomplished through various methods: (1) detection of adults, either by direct observation of suitable existing substrata where the mussels develop, or through deployment of artificial substrata that provide surface for colonization and (2) detection of the larval planktonic stage with the aid of plankton samples subsequently analyzed under the microscope or processed using molecular methods.

The presence of adults indicates that the invasion is already underway, also furnishing information on the population dynamics of the mussel. Monitoring of the larvae, on the other hand, may allow detection of the species before it has become firmly established and achieved extensive spread.

\section{Detection of Juveniles and Adults}

Invasion of the golden mussel created a new scenario for many ecosystem compartments, and particularly for the benthos (Darrigran 2002; Boltovskoy and Correa 2015; see "Relationships of Limnoperna fortunei with Benthic Animals" in this volume). Monitoring of golden mussel populations in order to quantify densities, establish their structure and reproductive status, and describe their growth can be carried out in the vicinity of water intakes that feed the cooling systems of industrial facilities, or even within the cooling systems themselves (see Pereira et al. 2012 for a selection of applicable methods).

Artificial substrates provide suitable surfaces for colonization by benthic organisms and are widely used in the study of freshwater sessile macroinvertebrates (see see Fig. 2 in Chapter "Population dynamics and growth of Limnoperna fortunei" in this volume). Experimental frames of various designs and materials (polyvinyl chloride (PVC), concrete, wood, ceramics, various plastics, nettings, fabrics, etc.) were used in several studies, both in South America (Boltovskoy and Cataldo 1999; Fontes et al. 2002; Darrigran et al. 2007; Queiroz et al. 2007; Sylvester et al. 2007; Santos et al. 2008; Sardiña et al. 2008; Bergonci et al. 2009; Mansur et al. 2009; Belz et al. 2010; Pereira et al. 2010; Volkmer Ribeiro et al. 2010; Bonel 2011) and in Asia (Morton 1977; Ohkawa et al. 1999; Matsui et al. 2001, 2002; Nagaya et al. 2001; Nakano et al. 2010, 2011; Xu et al. 2013). The use of artificial substrates has both advantages and disadvantages. Among the former, ease of sample retrieval and density estimates, as well as the ability to ascertain the initial time of colonization, are important. On the other hand, they can be vandalized, lost, broken, exposed to air thereby killing adhering organisms, or undergo excessive siltation thus precluding mussel settlement or even causing death of already established colonizers (Sylvester 2006). In order to preclude predation of the mussels settling on the exposed artificial 
substrata (predation can eliminate up to over $90 \%$ of $L$. fortunei biomass: Sylvester et al. 2007; Nakano et al. 2010), they can be protected with mesh or plastic netting. These enclosures can either be deployed barren of mussels, allowing the protected substrata to be colonized by drifting veligers and develop mussel beds, or stocked with mussels whose number and sizes have been pre-established, prior to deployment.

\section{Detection of Larvae}

\section{Light Microscopy}

Larvae of $L$. fortunei in the water column can be sought and quantified using plankton samples, obtained either by towing a net or by filtering a known volume of water with the aid of a suction pump (recommended when quantitative data are needed; see Boltovskoy 1981; Harris et al. 2000; Alder and Morales 2007; Suthers and Rissik 2009; Santos et al. 2012 for details on zooplankton sampling methods). This approach has been used extensively, usually to investigate seasonal changes in the reproductive activity of the mussel (see "Reproductive Output and Seasonality of Limnoperna fortunei" in this volume). However, precise abundance estimates are time consuming, and may require that large volumes of water be filtered, especially when larvae are scarce. If other molluscan species with planktonic larvae are present in the area, identification of different species will be also necessary (Ezcurra de Drago et al. 2006; Mansur et al. 2012a).

\section{Molecular Methods}

Pie et al. (2006) and Boeger et al. (2007) described a polymerase chain reaction (PCR)-based molecular method for the detection of L. fortunei larvae (see Tscha et al. 2012 for a detailed description). This method is very sensitive, detecting as little as $0.041 \mathrm{ng}$ of L. fortunei DNA (a single larva yields $28 \mathrm{ng}$ of DNA), or the equivalent of one larva in $200 \mathrm{~L}$ of water (Pie et al. 2006; Tscha et al. 2012). Typical larval densities range around 1 to $>20$ larvae/L (see "Reproductive Output and Seasonality of Limnoperna fortunei" in this volume). Thus, this technique allows confirmation of the presence of mussels at a very early stage, before they have been detected by direct observation (Darrigran et al. 2009).

Although the molecular PCR-based method allows assessing the presence of L. fortunei larvae with high accuracy, larval densities cannot be quantified. In the past decade, the use of real-time quantitative PCR (qPCR) became widespread for detecting and quantifying specific DNA in a DNA complex solution. This technique can be used for the quantification of planktonic organisms, including larvae of $L$. fortunei (Endo et al. 2009). Field-collected plankton is subjected to DNA extraction and qPCR analysis using specific primers for the golden mussel (developed from CO1). Highly specific amplification, formed by 138 bases, indicates the presence of 
larvae in a sample and the number of larvae can be assessed based on the amplification factor (Endo and Nogata 2012).

These molecular techniques are operationally faster than traditional methods, more accurate, and they do not require taxonomic knowledge for the identification of larvae. On the other hand, the economic costs of these analyses, especially when considering the hardware required, are significantly higher.

\section{Actions in the Natural Environment}

The mechanisms involved in biological invasions comprise two complementary components: one is associated with the ability of a given species to invade a new range ("invasiveness"), and the other is the susceptibility of a given environment to be invaded ("invasibility") (Hicks 2004). Both must be taken into account when designing suitable strategies for curtailing bioinvasions.

\section{Criteria for Defining an Invasive Species}

Scoring of harmful invasive species as a function of their nuisance may be necessary when priorities in resource allocation are unavoidable. Thus, management efforts focus on the most problematic invasive species. However, deciding which species should be fought first is often not a straightforward issue. Increasing awareness of bioinvasions and the problems they cause have resulted in a growing volume of scientific publications on this topic (Kolar and Lodge 2001), as well as an accumulation of technical terms, often synonymous (Colautti and MacIsaac 2004; Lockwood et al. 2007). This has hindered both investigation and decision-making processes associated with the management of bioinvasions. The Convention on Biological Diversity defines invasive species as those that thrive unaided by humans and threaten natural or seminatural habitats outside of their normal area of distribution. Some native species can become invasive when they are transported to other areas within the same country (Simkanin et al. 2009), or even to nearby regions within the same ecosystem, especially if conditions for their survival, growth, and expansion have been modified (see "Distribution and Colonization of Limnoperna fortunei: Special Traits of an Odd Mussel” in this volume) (Xu et al. 2014).

Valéry et al. (2008) pointed out that the most widespread criteria to define invasive species have been the biogeographic criteria and the criteria related with their impact. The biogeographic approach is fairly practical, since it is based on an objective assessment of geographic distribution. An introduced species is one that manages to overcome a geographic barrier. This criterion thus allows for fast implementation of management options at an early stage of transfer from the original range. The impact criterion, on the other hand, requires that, in order to be considered invasive, a species must have a larger impact in the invaded ecosystem than the one it has in its native range. Assessment of the magnitude of impact, however, is unclear and questionable. 
A more comprehensive definition of invasive species should be based on a series of requirements that the invasive species meets. As pointed out above, a biological invasion occurs when a species, aided by human activities, overcomes a number of barriers (Fig. 3), colonizes a new area where it acquires a competitive advantage, and grows rapidly in density and distribution. This may result in functional dominance of the system, which in turn can threaten native biodiversity and cause economic damage

\section{Designing a Plan for Sustainable Management of Invasive Species}

Cowie (2004) proposed three basic components for the conservation of biodiversity, which can also be useful for strategies of management of bioinvasions. The components are: (1) generation of scientific knowledge, (2) management, and (3) sociopolitical environment.

Scientific knowledge must reach the level of local and regional environmental organizations in order to help shape an adequate management plan. However, even when the requirements of scientific knowledge and management are met, without social awareness and support from environmental policies, conservation of biodiversity and management of bioinvasions can only succeed in small areas and for short periods. Social awareness is a sine qua non condition for active social involvement in the problem. Without it, success will be regionally restricted and temporally short. The social component is obviously the most complex of the three.

\section{Generation of Scientific Knowledge}

The results of scientific research aimed at assessing the risk of invasion should be explored and used by managers and decision makers. After the pioneering work of B. Morton in Hong Kong (Morton 1973, 1975, 1977, 1982; Morton et al. 1976), most subsequent information on L. fortunei has originated from South America (Argentina, Brazil, including several review books: Penchaszadeh 2005; Darrigran and Damborenea 2006, 2009; Mansur et al. 2012b) and Japan. In this context, investigations oriented at evaluating invasion risk and pathways, as well as possibilities of secondary spread (e.g., Darrigran and Pereyra 2011; Belz et al. 2012; Campos et al. 2012; Darrigran et al. 2012; Sylvester et al. 2013) are of particular significance. As noted by Hicks (2004), work on predicting future invasions is strongly lagging behind when compared to efforts dedicated to assessing impact of invasions that have already occurred. Investigations aimed at prediction, pathway analysis, and ecological scenario building that can be used in decision support systems are urgently needed (Hicks 2004). Some of this type of work has been done with L. fortunei (e.g., Kluza and McNyset 2005; Belz 2006, 2009; Oliveira et al. 2010; Campos 2014), but much more is needed. 
Fig. 2 Stages in the invasion process of a nonnative species, pointing out activities that need to be carried out at each stage

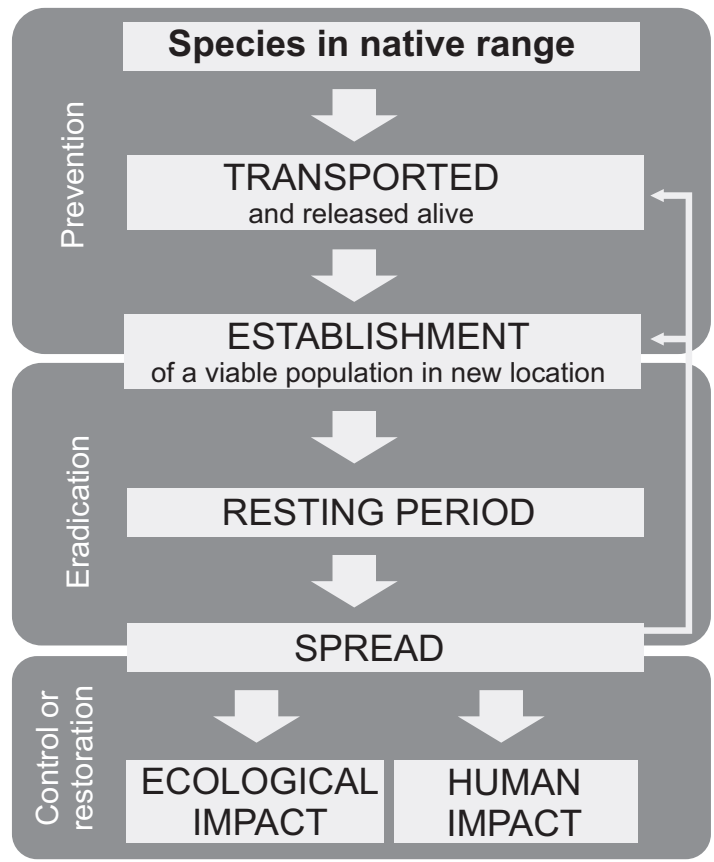

\section{Management Plan}

Human actions in response to impacts derived from biological invasions are often too late and too weak to significantly mitigate harm (Lodge et al. 2006). This is especially true for the golden mussel, where more than two decades after the introduction and extensive damage to many industrial installations (see "Impacts of Limnoperna fortunei on Man-made Structures And Control Strategies: General Overview" in this volume), none of the South American countries colonized by the mussel has developed a centralized, coordinated management strategy, and investment into research and management of this mussel remains very low. In Japan, no mussel quarantines have yet been implemented (see "Colonization and Spread of Limnoperna fortunei in Japan" in this volume).

Reversal of this trend will require coordinated management at various levels (regional, global) with federal or national leadership and the close cooperation of state and local government bodies (DePoorter 2009). Effectiveness in the early detection and prevention of biological invasions must increase significantly, thus allowing quick responses to new, potentially harmful introductions, and reducing the spread of existing invasions (Lodge et al. 2006). Actions and investments should be centralized and coordinated by a national center to maximize cost-effectiveness and sustainability of the control efforts.

Analysis of the components of an invasion (invasiveness and invasibility, Hicks 2004), and the stages of the invasion process (Figs. 2 and 3), indicate that each stage is characterized by very dissimilar attributes as to the feasibility and cost of 


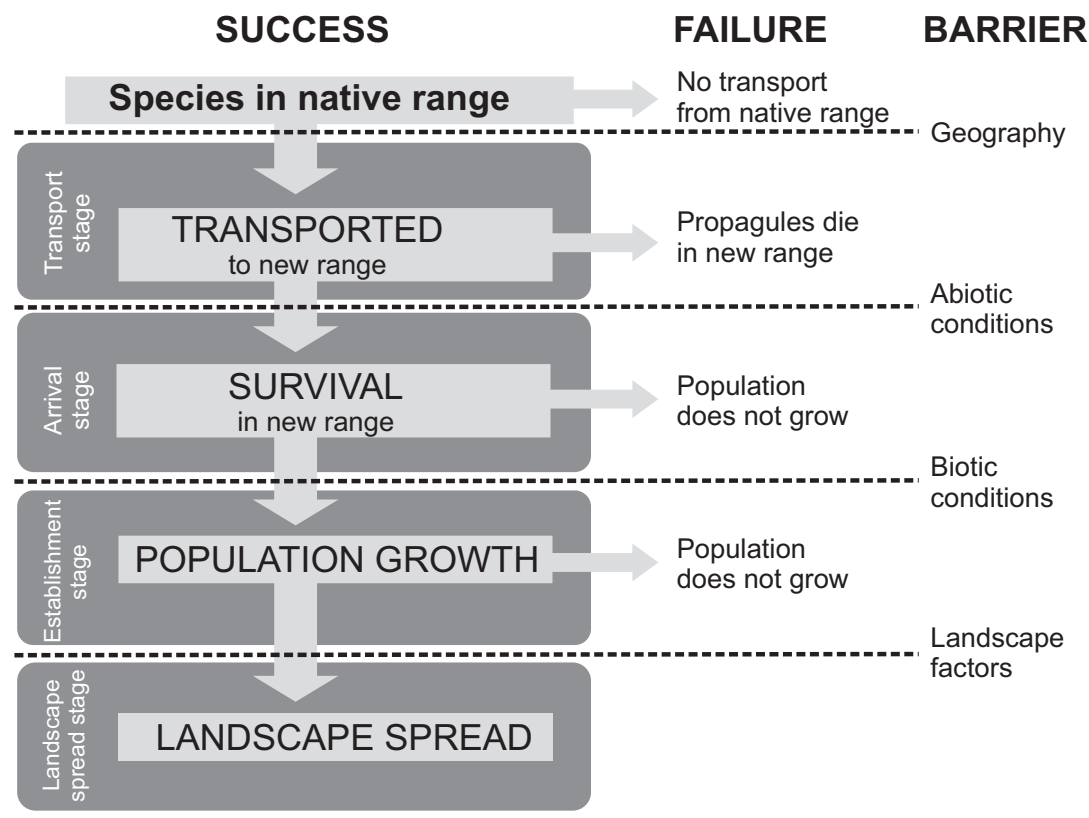

Fig. 3 A conceptual model of the invasion process of a species, highlighting the transition steps between the four stages of invasion

eradicating the invader, which depend, among others, on the ecosystem involved. These stages obviously also determine the best management option available. Management criteria and options eventually adopted, however, are often flawed and ineffective, partly because they do not take these variables into consideration, and partly because prior knowledge based on ad hoc studies is ignored or overlooked. Failure to consider conditions typical of each stage of the invasion can finally result in a useless management strategy. As suggested by Hicks (2004), the longer it takes to start taking action after a new species is introduced, the lower are the probabilities of its eradication and the higher the costs of coping with it. Thus, the best costto-benefit combination and the highest chances of eradication are restricted to the early stages of this process, which underscores the importance of early detection. By contrast, once the species has become conspicuous and widespread, the period of high cost-to-benefit ratio has already expired, and the probability of successful eradication is close to zero. By this time, the only remaining option is management of the invasion. Management efforts may be significant when the invasion affects human activities. On the other hand, when biodiversity or other ecosystem attributes are negatively affected but perceived by managers as of minor practical importance, the resulting management efforts are often minor.

Actions associated with reduction of the risk of entry, establishment, and dispersion of invasive species, including L. fortunei, fall into three main categories: (1) pre-border actions (adopted by the potential donor country/area aimed at precluding export of the species), (2) border actions, and (3) post-border (emergency) 
actions (Maynard and Nowell 2009). Each category, in turn, has two main components: physical (infrastructure, materials, finance) and human (legislation, procedures, capabilities). The first action arising from category (2) is quarantine. In order for quarantines to be effective, there must be a permanent compromise of physical and human resources guaranteeing infrastructure capacity, technical experience, communication capacity, and personnel training. Research on strategies aimed at mitigating bioinvasion-related problems often centers the attention on the receptor country or area, thus minimizing the responsibility of the donor side (Maynard and Nowell 2009). No safeguards are established enforcing the donor country to ensure that products and vectors (e.g., ships and trucks) leaving its ports comply with minimum requirements of safety as far as bioinvasions are concerned.

Lach et al. (2003) performed a survey exploring scientists' and the general public's expectations toward the role of scientists in communication, management, and policy. The five potential roles that research scientists might play were concluded to be: (1) reporting scientific results that others use in making decisions on natural resource management issues, (2) reporting and then interpreting scientific results for others who are involved in natural resource management decisions, (3) working closely with managers and others in integrating scientific results into management decisions, (4) actively advocating for specific and preferred natural resource management decisions, and (5) making decisions about natural resource management and policy. While scientists slightly preferred the interpretive role for themselves, other groups tended to prefer an integrative role for scientists. Most respondents were in favor of scientists getting involved in interpreting and helping to integrate the results of their science into policy decisions. This clearly is the best alternative for the sound management of many environmental issues, including bioinvasions. However, the administrative and political scenarios in many of the countries invaded by L. fortunei strongly hinder integration between administration and science.

\section{Developing Social Awareness}

Implementation of an integrated and sustainable management plan of biological invasions requires consideration of several components, including scientific knowledge and a blueprint for sound actions (Darrigran et al. 2008). Action must be taken at two levels: (1) in society in general, through formal and informal education with publicity strategies, documentaries, etc., seeking to generate demand at the following level and (2) among public officials, advocating for the development of norms and management programs to cope with bioinvasions in a timely manner and soundly.

An educational program aimed at the general public should include the following components: (1) it should inform society timely and thoroughly, making it aware of the ecological, economic, and social impacts that invasive species generate, including specifics as to the status and vulnerability of the different sectors endangered, (2) it should foster interinstitutional cooperation for the formation of specific work groups, timely participation of the communication media, and, above all, the co- 
operation of the different sectors involved, including civil organizations, and (3) it should implement programs in environmental education aimed at generating social awareness that will help prevent new introductions and facilitate early detection of nonnative species.

The economic burden of these actions is often lighter than that of control and eradication programs.

Acknowledgments This work was financially supported by the Consejo Nacional de Investigaciones Científicas y Técnicas (CONICET), Argentina, and by Projects N670 (Facultad de Ciencias Naturales y Museo, Universidad Nacional de La Plata, Argentina), and H648 (Facultad de Humanidades y Ciencias de la Educación, Universidad Nacional de La Plata, Argentina).

\section{References}

Alder VA, Morales CE (eds) (2007) Manual de métodos para el estudio de sistemas planctónicos marinos. Eudeba, Buenos Aires, pp 1-266

Belz CE (2006) Análise de risco de bioinvasão por Limnoperna fortunei (Dunker, 1857): um modelo para a bacia do rio Iguaçu, Paraná. PhD Thesis, Universidade Federal do Paraná (Brazil), pp $1-102$

Belz C (2009) Análise de risco aplicada às bioinvasões. In: Darrigran GA, Damborenea C (eds) Introdução a biologia das invasões. O mexilhão dourado na América do Sul: biologia, dispersão, impacto, prevenção e controle. Cubo Editora, São Carlos, pp 229-245

Belz CE, Darrigran GA, Bonel N, Mader Netto OS (2010) Density, recruitment, and shell growth of Limnoperna fortunei (Mytilidae), an invasive mussel in tropical South America. J Freshw Ecol 25:227-233

Belz CE, Darrigran GA, Netto OSM, Boeger WA, Ribeiro PJ (2012) Analysis of four dispersion vectors in inland waters: the case of the invading bivalves in South America. J Shellfish Res 31:777-784

Bergonci PEA, Mansur MCD, Pereira D, Santos CP (2009) Population sampling of the golden mussel, Limnoperna fortunei (Dunker, 1857), based on artificial ceramic substrate. Biotemas 22:85-94

Boeger WA, Pie MR, Falleiros RM, Ostrensky A, Darrigran GA, Mansur MCD, Belz CE (2007) Testing a molecular protocol to monitor the presence of golden mussel larvae (Limnoperna fortunei) in plankton samples. J Plankton Res 29:1015-1019

Boltovskoy D (1981) Redes. In: Boltovskoy D (ed) Atlas del Zooplancton del Atlántico Sudoccidental y métodos de trabajo con el zooplancton marino. Instituto Nacional de Investigación y Desarrollo Pesquero, Mar del Plata, pp 15-35

Boltovskoy D, Cataldo D (1999) Population dynamics of Limnoperna fortunei, an invasive fouling mollusc, in the lower Paraná River (Argentina). Biofouling 14:255-263

Boltovskoy D, Correa N (2015) Ecosystem impacts of the invasive bivalve Limnoperna fortunei (golden mussel) in South America. Hydrobiologia 746:81-95

Boltovskoy D, Correa N, Cataldo D, Sylvester F (2006) Dispersion and ecological impact of the invasive freshwater bivalve Limnoperna fortunei in the Río de la Plata watershed and beyond. Biol Invasions 8:947-963

Bonel N (2011) Demografía experimental de un bivalvo invasor, Limnoperna fortunei (Dunker, 1857), en la cuenca del Plata. PhD Thesis, Universidad Nacional de La Plata (Argentina), pp $1-180$

Campos MCS (2014) Modelagem matemática do processo de invasão de Limnoperna fortunei (Dunker, 1857). Fundação Centro Tecnológico de Minas Gerais (Brazil). Technical Report 
GT 343, Controle do Mexilhão Dourado: Bioengenharia e novos materiais para aplicações em ecossistemas e usinas hidrelétricas, pp 3-36

Campos MCS, Lanzer R, Castro PT (2012) Hydrological stress as a limiting factor of the invasion of Limnoperna fortunei (Dunker, 1857) in the Upper Paraná River (Brazil). Acta Limnologica Brasiliensia,24:64-82

Colautti RI, MacIsaac HJ (2004) A neutral terminology to define 'invasive' species. Divers Distrib 10:135-141

Cowie RH (2004) Disappearing snails and alien invasions: the biodiversity/conservation interface in the Pacific. J Conchol (Special Publication) 3:23-37

Darrigran GA (2002) Potential impact of filter-feeding invaders on temperate inland freshwater environments. Biol Invasions 4:145-156

Darrigran GA (2010) Summary of the distribution and impact of the golden mussel in Argentina and neighboring countries. In: Mackie GL, Claudi R (eds) Monitoring and control of macrofouling mollusks in fresh water systems. CRC Press, Boca Raton, pp 389-396

Darrigran GA, Damborenea C (2005) A South American bioinvasion case history: Limnoperna fortunei (Dunker, 1857), the golden mussel. Am Malacol Bull 20:105-112

Darrigran GA, Damborenea C (eds) (2006) Bioinvasión del mejillón dorado en el continente americano. Editorial Universitaria de La Plata, La Plata, pp 1-221

Darrigran GA, Damborenea C (eds) (2009) Introdução a biologia das invasões. O Mexilhão Dourado na América do Sul: biologia, dispersão, impacto, prevenção e controle. Cubo Editora, Sao Carlos, pp 1-245

Darrigran GA, Damborenea C (2011) Ecosystem engineering impact of Limnoperna fortunei in South America. Zool Sci 28:1-7

Darrigran G, Mansur MCD (2009) Introdução e dispersão do Limnoperna fortunei. In: Darrigran G, Damborenea C (eds) Introdução a biologia das invasões. O mexilhão dourado na América do Sul: biologia, dispersão, impacto, prevenção e controle. Cubo Editora, São Carlos, pp 89-109

Darrigran GA, Pastorino G (1995) The recent introduction of a freshwater Asiatic bivalve, Limnoperna fortunei (Mytilidae) into South America. The Veliger 38:171-175

Darrigran GA, Pereyra P (2011) Estandarización de métodos de control para Limnoperna fortunei. In: Tópicos em malacologia, Ecos do XIX Encontro Brasileiro de Malacologia, Rio de Janeiro (Brazil)

Darrigran GA, Damborenea C, Greco N (2007) An evaluation pattern for antimacrofouling procedures: Limnoperna fortunei larvae study in a hydroelectric power plant in South America. Ambio 36:575-579

Darrigran GA, Vilches A, Legarralde T (2008) Desinterés del pasado, decisiones del futuro: educación para prevenir las invasiones biológicas. Revista Educación en Biología 11:39-52

Darrigran GA, Boeger W, Damborenea C, Maroñas M (2009) Evaluation of sampling and analysis techniques for early detection of Limnoperna fortunei (Mytilidae) in limit areas of its distribution. Braz J Biol 69:979-980

Darrigran GA, Damborenea C, Drago EC, Ezcurra de Drago I, Paira A, Archuby F (2012) Invasion process of Limnoperna fortunei (Bivalvia: Mytilidae): The case of Uruguay River and emissaries of the Esteros del Iberá Wetland, Argentina. Zoologia 29:531-539

DePoorter M (2009) International legal instruments and frameworks for invasive species. In: Clout MN, Williams PA (eds) Invasive species management: a handbook of principles and techniques. Oxford University Press, New York, pp 108-140

Endo N, Nogata Y (2012) Método de detecção e quantificação de larvas do mexilhão-dourado Limnoperna fortunei, usando PCR quantitativo em tempo real. In: Mansur MCD, Santos CP, Pereira D, Padula Paz IC, Leite Zurita ML, Raya Rodriguez MT, Vilar Nehrke M, Aydos Bergonci PE (eds) Moluscos límnicos invasores no Brasil. Biologia, prevenção, controle. Redes Editora, Porto Alegre, pp 149-153

Endo N, Sato K, Nogata Y (2009) Molecular based method for the detection and quantification of larvae of the golden mussel Limnoperna fortunei using real-time PCR. Plankton Benthos Res 4:125-128 
Ezcurra de Drago I, Montalto L, Oliveros OB (2006) Desarrollo y ecología larval de Limnoperna fortunei. In: Darrigran G, Damborenea C (eds) Bio-invasión del mejillón dorado en el continente americano. Editorial de la Universidad de La Plata, La Plata, pp 85-93

Fontes HM, Takeda AM, Fugita DS (2002) Experience in Itaipu reservoir (Brazil) with artificial substrate (in situ): is it best way of monitoring an invading species like Limnoperna fortunei (Bivalvia, Mytilidae)? In: International Symposium on Reservoir Management in Tropical and Sub-Tropical Regions, Foz do Iguaçu (Brazil)

Harris RP, Wiebe PH, Lenz J, Skjoldal HR, Huntley M (eds) (2000) ICES Zooplankton methodology manual. Academic Press, San Diego, pp 1-684

Hicks G (2004) Turning the tide: Is aquatic bioinvaders research heading in the right direction? Aquat Invaders 15:9-20

Jones CG, Lawton JH (1994) Organisms as ecosystem engineers. Oikos 69:373-386

Kluza DA, McNyset KM (2005) Ecological niche modeling of aquatic invasive species. Aquat Invaders 16:1-7

Kolar CS, Lodge DM (2001) Progress in invasion biology: predicting invaders. Trends Ecol Evol 16:199-204

Lach D, List P, Steel B, Shindler B (2003) Advocacy and credibility of ecological scientists in resource decisionmaking: a regional study. BioScience 53:170-178

Lockwood J, Hoopes M, Marchetti M (2007) Invasion ecology. Blackwell, Malden, pp 1-304

Lodge DM, Williams S, MacIsaac HJ, Hayes KR, Leung B, Reichard S, Mack RN, Moyle PB, Smith M, Andow DA, Carlton JT, McMichael A (2006) Biological invasions: recommendations for U.S. policy and management. Ecol Appl 16:2035-2054

MacIsaac HJ, Grigorovich IA, Ricciardi A (2001) Reassessment of species invasions concepts: the Great Lakes basin as a model. Biol Invasions 3:405-416

Mackie GL, Claudi R (2010) Monitoring and control of macrofouling mollusks in fresh water systems. CRC Press, Boca Raton, pp 1-508

Mansur MCD, Pereira D, Santos CP, Bergonci PEA, Thormann BM, Takeda AM (2009) Colonização de substrato artificial pelo mexilhão dourado, Limnoperna fortunei (Dunker, 1857) (Bivalvia, Mytiloida, Mytilidae), no Delta do Rio Jacuí (RS, Brasil). Biotemas 22:75-80

Mansur MCD, Mansur Pimpao D, Bergonci PEA, Santos CP, Santos de Figueiredo GC (2012a) Morfologia e ciclo larval comparados de bivalves límnicos invasores e nativos. In: Mansur MCD, Santos CP, Pereira D, Padula Paz IC, Leite Zurita ML, Raya Rodriguez MT, Vilar Nehrke M, Aydos Bergonci PE (eds) Moluscos límnicos invasores no Brasil. Biologia, prevenção, controle. Redes Editora, Porto Alegre, pp 95-110

Mansur MCD, Santos CP, Pereira D, Padula Paz IC, Leite Zurita ML, Raya Rodriguez MT, Vilar Nehrke M, Aydos Bergonci PE (eds) (2012b) Moluscos límnicos invasores no Brasil. Biologia, prevenção, controle. Redes Editora, Porto Alegre, pp 1-411

Matsui Y, Nagaya K, Yuasa A, Naruto H, Yamamoto H, Ohkawa K, Magara Y (2001) Attachment strength of Limnoperna fortunei on substrates, and their surface properties. Biofouling 17:29-39

Matsui Y, Nagaya K, Funahashi G, Goto Y, Yuasa A, Yamamoto H, Ohkawa K, Magara Y (2002) Effectiveness of antifouling coatings and water flow in controlling attachment of the nuisance mussel Limnoperna fortunei. Biofouling 18:137-148

Maynard G, Nowell D (2009) Biosecurity and quarantine for preventing invasive species. In: Clout MN, Williams PA (eds) Invasive species management: a handbook of principles and techniques. Oxford University Press, Oxford, pp 1-18

Morton B (1973) Some aspects of the biology and functional morphology of the organs of feeding and digestion of Limnoperna fortunei (Dunker) (Bivalvia: Mytilacea). Malacologia 12:265281

Morton B (1975) The colonization of Hong Kong's raw water supply system by Limnoperna fortunei (Dunker 1857) (Bivalvia: Mytilacea) from China. Malacol Rev 8:91-105

Morton B (1977) The population dynamics of Limnoperna fortunei (Dunker 1857) (Bivalvia: Mytilacea) in Plover Cove Reservoir, Hong Kong. Malacologia 16:165-182 
Morton B (1982) The reproductive cycle in Limnoperna fortunei (Dunker, 1857) (Bivalvia: Mytilidae) fouling Hong Kong's raw water sypply system. Oceanologia et Limnologia Sinica $13: 312-324$

Morton B, Dinesen G (2010) Colonization of Asian freshwaters by the Mytilidae (Bivalvia): A comparison of Sinomytilus harmandi from the Tonle-Sap River, Phnom Penh, Cambodia, with Limnoperna fortunei. Molluscan Res 30:57-72

Morton B, Au CS, Lam WW (1976) Control of Limnoperna fortunei. J Inst Water Eng Sci 30:147156

Nagaya K, Matsui Y, Ohira H, Yuasa A, Yamamoto H, Ohkawa K, Magara Y (2001) Attachment strength of an adhesive nuisance mussel, Limnoperna fortunei, against water flow. Biofouling 17:263-274

Nakano D, Kobayashi T, Sakaguchi I (2010) Predation and depth effects on abundance and size distribution of an invasive bivalve, the golden mussel Limnoperna fortunei, in a dam reservoir. Limnology 11:259-266

Nakano D, Kobayashi T, Endo N, Sakaguchi I (2011) Growth rate and settlement of Limnoperna fortunei in a temperate reservoir. J Molluscan Stud 77:142-148

Nishimura T, Habe T (1987) Chinese freshwater mussels mixed in the imported Corbicula clam. Chiribotan (J Malacol Soc Jpn) 18:110-111

Ohkawa K, Nishida A, Honma R, Matsui Y, Nagaya K, Yuasa A, Yamamoto H (1999) Studies on fouling by the freshwater mussel Limnoperna fortunei and the antifouling effects of low energy surfaces. Biofouling 13:337-350

Oliveira MD, Hamilton SK, Jacobi CM (2010) Forecasting the expansion of the invasive golden mussel Limnoperna fortunei in Brazilian and North American rivers based on its occurrence in the Paraguay River and Pantanal wetland of Brazil. Aquat Invasions 5:59-73

Penchaszadeh PE (ed) (2005) Invasores. Invertebrados bentónicos introducidos en el Río de la Plata y región costera marina aledaña. Eudeba, Buenos Aires, pp 1-384

Pereira D, Mansur MCD, Volkmer-Ribeiro C, Oliveira MD, Santos CP, Bergonci PEA (2010) Colonização de substrato artificial por macroinvertebrados límnicos, no delta do Rio Jacuí (RS, Brasil). Biotemas 23:101-110

Pereira D, Arruda JA, Bergonci PEA, Oliveira AS, Postiglione R, Mansur MCD (2012) Como monitorar moluscos límnicos invasores bentônicos e macroinvertebrados associados? In: Mansur MCD, Santos CP, Pereira D, Padula Paz IC, Leite Zurita ML, Raya Rodriguez MT, Vilar Nehrke M, Aydos Bergonci PE (eds) Moluscos límnicos invasores no Brasil. Biologia, prevenção, controle. Redes Editora, Porto Alegre, pp 155-184

Pie MR, Boeger WA, Patella L, Falleiros RM (2006) A fast and accurate molecular method for the detection of larvae of the golden mussel Limnoperna fortunei (Mollusca: Mytilidae) in plankton samples. J Molluscan Stud 72:218-219

Pimentel D (ed) (2002) Biological invasions. Economic and environmental costs of alien plant, animal, and microbe species. CRC Press, Boca Raton, pp 1-369

Queiroz JF, Silveira MP, Sitton M, Marigo ALS, Zambon GV, Silva JR, Carvalho MP, Ribacinko DB (2007) Coletor de macroinvertebrados bentônicos com substrato artificial para monitoramento da qualidade de água em viveiros de produção de tilápia. EMBRAPA(Brazil). Circular Técnica 16, pp 1-5

Santos CP, Mansur MCD, Wurdig NL (2008) Variaçoes no comprimento dos individuos de uma populacão do mexilhão dourado, Limnoperna fortunei (Mollusca: Bivalvia: Mytilidae), ao longo do ano, na Praia do Veludo, Lago Guaiba, Rio Grande do Sul, Brasil. Braz J Biol 25:389-396

Santos CP, Vilar Nehrke M, Mansur MCD, Gazulha V (2012) Como monitorar bivalves invasores no plâncton? Método da microscopia óptica. In: Mansur MCD, Santos CP, Pereira D, Padula Paz IC, Leite Zurita ML, Raya Rodriguez MT, Vilar Nehrke M, Aydos Bergonci PE (eds) Moluscos límnicos invasores no Brasil. Biologia, prevenção, controle. Redes Editora, Porto Alegre, pp 139-142

Sardiña P, Cataldo D, Boltovskoy D (2008) The effects of the invasive mussel, Limnoperna fortu$n e i$, on associated fauna in South American freshwaters: importance of physical structure and food supply. Fund Appl Limnol/Archiv Hydrobiologie 173:135-144 
Simkanin C, Davidson I, Falkner M, Sytsma M, Ruiz G (2009) Intra-coastal ballast water flux and the potential for secondary spread of non-native species on the US West Coast. Marine Pollut Bull 58:366-374

Suthers IM, Rissik D (eds) (2009) Plankton. A guide to their ecology and monitoring for water quality. CSIRO, Collingwood, pp 1-256

Sylvester F (2006) Biología alimentaria y ecología del molusco invasor Limnoperna fortunei (Mytilidae) en el Paraná inferior y Río de la Plata. PhD Thesis, Universidad de Buenos Aires (Argentina), pp 1-160

Sylvester F, Boltovskoy D, Cataldo D (2007) Fast response of freshwater consumers to a new trophic resource: Predation on the recently introduced Asian bivalve Limnoperna fortunei in the lower Parana River, South America. Austral Ecol 32:403-415

Sylvester F, Cataldo D, Notaro C, Boltovskoy D (2013) Fluctuating salinity improves survival of the invasive freshwater golden mussel at high salinity: implications for the introduction of aquatic species through estuarine ports. Biol Invasions 15:1355-1366

Tscha MK, Patella R, Ostrensky A, Boeger WA (2012) O método molecular de prospecção do mexilhão-dourado. In: Mansur MCD, Santos CP, Pereira D, Padula Paz IC, Leite Zurita ML, Raya Rodriguez MT, Vilar Nehrke M, Aydos Bergonci PE (eds) Moluscos límnicos invasores no Brasil. Biologia, prevenção, controle. Redes Editora, Porto Alegre, pp 143-148

Valéry L, Fritz H, Lefeuvre J, Simberloff D (2008) In search of a real definition of the biological invasion phenomenon itself. Biol Invasions 10:1345-1351

Volkmer Ribeiro C, Parolin M, Fürstenau-Oliveira K, De Menezes ER (2010) Colonization of hydroelectric reservoirs in Brazil by freshwater sponges, with special attention on Itaipu. Interciencia 35:340-347

Xu M, Wang ZY, Lin CC, Pan BZ, Zhao N (2013) Experimental study of invasion and biofouling of freshwater mussel Limnoperna fortunei. Int J Geosci 4:1-7

Xu M, Darrigran G, Wang Z, Zhao N, Lin CC (2014) Experimental study on control of Limnoperna fortunei biofouling in water transfer tunnels. J Hydro-environment Res (in press) 